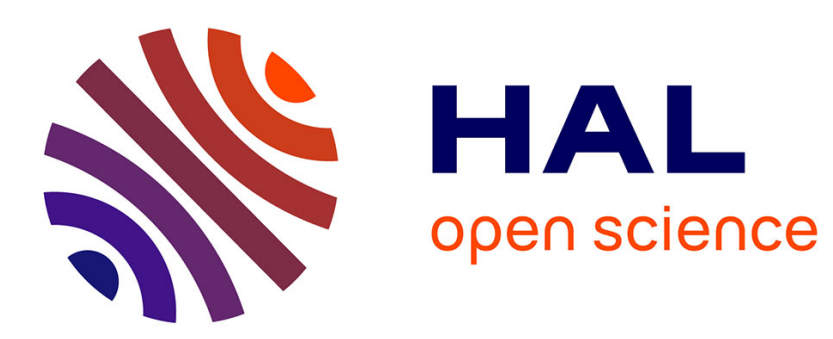

\title{
The origin of particulate organic carbon in the marine atmosphere as indicated by its stable carbon isotopic composition
}

\author{
R. Chesselet, M. Fontugne, P. Buat-Ménard, U. Ezat, C.E. Lambert
}

\section{- To cite this version:}

R. Chesselet, M. Fontugne, P. Buat-Ménard, U. Ezat, C.E. Lambert. The origin of particulate organic carbon in the marine atmosphere as indicated by its stable carbon isotopic composition. Geophysical Research Letters, 1981, 8 (4), pp.345-348. 10.1029/GL008i004p00345 . hal-03413117

\author{
HAL Id: hal-03413117 \\ https://hal.science/hal-03413117
}

Submitted on 3 Nov 2021

HAL is a multi-disciplinary open access archive for the deposit and dissemination of scientific research documents, whether they are published or not. The documents may come from teaching and research institutions in France or abroad, or from public or private research centers.
L'archive ouverte pluridisciplinaire $\mathbf{H A L}$, est destinée au dépôt et à la diffusion de documents scientifiques de niveau recherche, publiés ou non, émanant des établissements d'enseignement et de recherche français ou étrangers, des laboratoires publics ou privés. 
GEOPHYSICAL RESEARCH LETTERS, VOL. 8, NO. 4, PAGES 345-348, APRIL 1981

THE ORIGIN OF PARTICULATE ORGANIC CARBON IN THE MARINE ATMOSPHERE AS INIICATED BY ITS STABLE CARBON ISOTOPIC COMPOSITION

R. Chesselet, M. Fontugne, P. Buat-Ménard, U. Ezat and C.E. Lambert

Centre des Faibles Radioactivités, Laboratoire mixte CNRS-CEA, 91190 Gif-sur-Yvette, France

Abstract. Organic carbon concentration and isotopic composition were determined in samples of atmospheric particulate matter collected in 1979 at remote marine locations (Enewetak atoll, Sargasso Sea) during the SEAREX (Sea-Air Exchange) program field experiments. Atmospheric Particulate Organic Carbon ( $P O C$ ) concentrations were found to be in the range of 0.3 to $1.2 \mu \mathrm{g} \cdot \mathrm{m}^{-3}$, in agreement with previous literature data. The major mass of POC was found on the smallest particles $(r<0.5 \mu \mathrm{m})$. The ${ }^{13} \mathrm{C} /{ }^{12} \mathrm{C}$ of the small particles is close to the one expected $\left(\delta^{13} \mathrm{C}=26+2 \%\right)$ for atmospheric POC of continental origin. For all the samples analysed so far, it appears that more than $80 \%$ of atmospheric POC over remote marine areas is of continental origin. This can be explained either by long-range transport of small sized continental organic aerosols or by the production of POC in the marine atmosphere from a vapor phase organic carbon pool of continental origin. The POC in the large size fraction of marine aerosols $(<20 \%$ of the total concentration) is likely to have a direct marine origin since its carbon isotopic composition is close to the expected value $\left(\delta^{13} \mathrm{C}=\right.$ $-21 \pm 2 \%$ ) for $P O C$ associated with sea-salt droplets transported to the marine atmosphere.

\section{Introduction}

In the last years, there has been an increasing interest in the study of organic material, both particulate and vapor phase, in the marine atmosphere. There is now some evidence that the presence of this material can be due not only to sea to air transfer processes but also to the long-range transport in the troposphere of trace organic substances, either natural or man-made, from the continerits to the open ocean (Duce, 1978; Marty et al., 1979 ; Eichmam et al., 1980). However, little is yet known about the relative importance of marine versus terrestrial sources with respect to the budget of the non-methane organic carbon in the global troposphere (Duce, 1978). Such an evaluation is critical for the determination of the flux of organic carbon from the continents to the ocean via atmospheric deposition. Since it has been shown that the stable carbon isotopic composition of contirental organic matter is different from that of marine organic matter (Sackett, 1964 ; Parker, 1971), we thought that this difference could be used in order to characterize the source of organic carbon over the ocean. In this paper, we report the first data on the stable carbon isotopic composition of Particulate Onganic Carbon (POC) over the sea and we show that the use of such an information is useful in assessing the origin of $P O C$ in the marine atmosphere.

Copyright 1981 by the American Geophysical Union.

\section{Experimental procedures}

During the Sea-Air Exchange Program (SEAREX ; Duce, 1981) field experiments, 20 atmospheric particulate samples were collected in 1979 for the determination of POC concentration and isotopic composition. The samples were collected from a $20 \mathrm{~m}$ high tower located on unhabited Bokandretok Island, Enewetak atoll, $11^{\circ} \mathrm{N}$ and $162^{\circ} \mathrm{E}$, and from a bow tower on board the R/V "Endeavor", $15 \mathrm{~m}$ above sea level, in the Sargasso Sea (cruise EN 039). Sampling was carefully controlled by wind speed and direction and by total condensation nuclei counts in the air in order to reduce possible local contamination at a minimum. Bulk aerosol samples were collected by high volume air filtration $\left(70 \mathrm{~m}^{3}\right.$. $\mathrm{h}^{-1}$ ) on $20 \times 25 \mathrm{~cm}$ pre-cleaned glass fiber filters (Whatman GF/C or Gelman A/E). Sampling duration was about one week at Enewetak and 2 to 5 days over the Sargasso Sea. At Enewetak, size separated aerosol samples were collected simultaneously with a Sierra model 235 high volume 5-stage cascade impactor operating at $68 \mathrm{~m}^{3} \cdot \mathrm{h}^{-1}$. Pre-cleaned glass fiber collection surfaces were used.

One quarter of each glass fiber filter was analysed for Na by atomic absorption spectrometry in order to estimate the sea-salt concentration at the atmospheric sampling sites. For the determination of atmospheric POC concentration and isotopic composition, $1 / 4$ or $1 / 8$ of each filter was analysed. This was done by mass spectrometry, using a high temperature dry oxidation method for the oxidation of organic matter to $\mathrm{CO}_{2}$ (Fontugne and Duplessy, 1978). Frior to oxidation, the inorganic carbon in the form of carbonates was removed by allowing the filters to be in the presence of vapor-HCl fumes. After oxidation, the $\mathrm{CO}_{2}$ was $\mathrm{pu}-$ rified through various steps and analysed using a Micromass $602 \mathrm{D}$ spectrometer.

The isotopic ratio $13 \mathrm{C} / 12 \mathrm{C}$ of the organic carbon of the samples is expressed as :

${ }^{13} \mathrm{C}=\left\{\left({ }^{13} \mathrm{C} /{ }^{12} \mathrm{C}(\right.\right.$ sample $){ }^{13} \mathrm{C} /{ }^{12} \mathrm{C}($ standard $\left.\left.)\right)-1\right\} \times 1000$

The standard used is the Chicago PDB-1 Standard. The calibration of our laboratory standard was made through comparison with the isotopic standards NBS 20 and NBS 21. For a few hundred $\mu g$ of carbon, the uncertainty on the $\delta^{13} \mathrm{C}$ is about $0.1 \%$ The quantitative analysis of the organic carbon content of the samples was done as follows : aliquots of our graphite laboratory standards were weighed, then burnt, and the intensity of the mass 44 peak was measured for the $\mathrm{CO}_{2}$ produced by the combustion of each aliquot. The calibration curve for a range of 50 to $1000 \mu \mathrm{g}$ of carbon gave a coefficient of correlation between the mass 44 peak intensity and the weight of carbon $r>0.998$. The mean absolute error on the carbon weight ranges from 20 to $60 \mu g$, depending on calibration series. 
As mentioned earlier, the glass fiber filters were pre-cleaned in order to lower their organic carbon content. This was done by combustion $(4 \mathrm{~h}$ at $450^{\circ} \mathrm{C}$ ) for the Enewetak dry season samples and by solvent extraction, using chloroform as the cleaning agent in a Soxhlet apparatus, for the Enewetak wet season samples and the Sargasso Sea samples. Table 1 presents the results of the anaIyses of comprehensive blank filters which were processed in the same way as their corresponding filter samples, except for air filtration. Mean organic carbon blanck values are similar to those previously reported by Sharp (1974). It is clear from Table 1 that in the present work the solvent extraction technique allowed a much better reproducibility of the organic carbon content and isotopic composition of the blank filters. Using this technique, the reproducibility of the $\delta^{13} \mathrm{C}$ of the blank filters was $0.3 \%$, similar to that of our laboratory standard.

\section{Results and Discussior}

Results from the analysis of 3 high volume cascade impactor and corresponding bulk filter samples from the Enewetak site, 2 from the dry season and 1 from the wet seasor, are given in Table 2. Results from the analysis of the 4 samples collected over the Sargasso Sea are given in Table 3.

It appears from Table 2 and Table 3 that both at Enewetak and over the Sargasso Sea the isotopic composition and the concentration of POC show little variation with time. The range of the $\delta^{13} \mathrm{C}$ is -26.5 to $-26.7 \%$ at Enewetak and -25.5 to $-26.4 \%$ over the Sargasso Sea. The range of the POC conceritration is 0.4 to $1.2 \mu \mathrm{g} \mathrm{m}^{-3}$, much smaller than the range of the Na concentration, 0.2 to $9.4 \mu \mathrm{g} . \mathrm{m}^{-3}$. Total POC concentrations which we observe are close to the ones previously observed in the marine atmosphere by Hoffman and Duce (1977). Also, as found by these authors, our 3 cas cade impactor samples indicate that more than $80 \%$ of the POC in the marine atmosphere is present on the smallest particles $(r<0.25 \mu \mathrm{m})$. The isotopic composition of the organic carbon in this size fraction is close to the isotopic composition of the organic carbon in the bulk filter samples and shows also very little variation from sample to sample.

As supported by the following considerations, our isotopic measurements strongly support the hypothesis of long-range transport of POC of continental origin as the major source for POC in the remote marine atmosphere :

a) The potential sources of atmospheric POC of continental origin include release by vegetation, forest fires, coal and petroleum burnings. Data from the literature show that the organic carbon of

TABLE 1. Results of blank filter analyses

\begin{tabular}{llcrc}
\hline & $\begin{array}{c}\text { POCug.cm } \\
\text { mean }\end{array}$ & $\sigma$ & $\delta^{13} \mathrm{C}$ & $\%$ \\
mean & $\sigma$ \\
\hline $\begin{array}{l}\text { Precombusted filter } \\
\text { Solvent extracted }\end{array}$ & 1.8 & 0.8 & -22.8 & 3.2 \\
filter & 1.8 & 0.2 & -24.6 & 0.3 \\
\hline
\end{tabular}

Mean and standard deviation for 5 cascade impactor filter collection surfaces and $220 \times 25 \mathrm{~cm}$ Eilters. these sources has a rather uniform isotopic composition with a mean $\delta^{13} \mathrm{C}$ of $-26 \pm 2 \%$ (Sackett, 1964 ; Parker, 1971). This $\delta^{13} \mathrm{C}$ could then be inferred for atmospheric POC of continental origin. This hypothesis is supported by our results which show $\delta^{13} \mathrm{C}$ of $-24.5 \%$ for atmospheric POC in the semi-rural environment of Gif-sur-Yvette, France, and $\delta^{13} \mathrm{C}$ of $-25.8 \%$ for atmospheric POC over Paris. Thus, it appears that the isotopic composition which we observe for POC in the marine atmosphere is close to the isotopic composition of continental sources.

b) Data from the literature (Williams and Gordon, 1970; Eadie et al, ,1978; Fontugne and Duplessy, 1978, 1981) and our results from the analysis of samples collected in Sargasso Sea surface waters indicate that for low latitude regions $\left(40^{\circ} \mathrm{S}-50^{\circ} \mathrm{N}\right)$, organic carbon in the sea has a $\delta^{13} \mathrm{C}$ of $-21 \pm 2 \%$. This takes into account data for all the poterstial sources of POC of marine origin in the atmosphere : plankton, particulate and dissolved orgaric carbor in surface seawater. All these data may suggest that atmospheric POC derived from the sea surface also has a $\&^{13} C$ of $-21 \pm 2 \%$ if one assumes no isotopic fractionation of organic carbon during the sea to air transfer of organic material. Clearly, this isotopic composition is very different from the one which we observe for total atmospheric POC over the sea.

From a quantitative aspect, $C_{m}$ and $C_{c}$, respectively the marine and continental components of the atmospheric POC concentration, $C_{\text {sample, can in }}$ principle be calculated by solving these 2 equations: $C_{m}+C_{c}=C_{\text {sample }}$

$\delta^{13} \mathrm{C}$ sample $=\frac{C_{m}\left(\delta^{13} C\right)_{m}+C_{c}\left(\delta^{13} C\right)_{c}}{C_{m}+C_{c}}$

where $\left(\delta^{13} \mathrm{C}\right)_{\mathrm{m}}$ and $\left(\delta^{13} \mathrm{C}\right)_{\mathrm{c}}$ are the above mentioned assigned values for atmospheric POC of marine and continental origin respectively. From our results, organic carbon of continental origin would account for more than $80 \%$ of the total atmospheric POC at Enewetak and over the Sargasso Sea. These results imply also that this continental component of atmospheric POC is mainly present on the smallest particles $(r<0.25 \mu \mathrm{m})$.

The isotopic composition of organic carbon in the large size fraction of the marine aerosol at Enewetak (Table 2) exhibits large uncertainties due to the small amount of organic carbon present (less than $20 \%$ of the total POC) and the variability of the $\delta^{13} \mathrm{C}$ of the blank filters. Nevertheless, it indicates a direct marine origin for the large particle POC. As shown by the size distribution of the $\mathrm{Na}$ concentration, the sea-salt fraction is mainly present on the first 2 stages of the cascade impactor $(r<0.75 \mu \mathrm{m})$. The isotopic composition of POC for this size fraction is closer to the expected value for POC associated with sea-salt droplets transported to the marine atmosphere $\left(\delta^{13} \mathrm{C}=-21 \%\right)$ than to the expected value for $\mathrm{POC}$ of continental origin $\left(\delta^{13} \mathrm{C}=-26 \%\right)$. The fact that, at Enewetak, the $\delta^{13} \mathrm{C}$ of the final filters of the cascade impactor samples, -27.2 to $-27.9 \%$ (Table 2 ), is significantly more depleted in ${ }^{i 3} \mathrm{C}$ than the bulk filter samples, -26.5 to $26.7 \%$, supports this conclusion. Assuming that the large particle POC is of marine origin implies an enrichment of organic carbon of a factor 100 in sea-borne aerosols over bulk seawater. This is in agreement with results from laboratory experiments 
TABLE 2. Results for Enewetak air samples

\begin{tabular}{|c|c|c|c|c|c|c|c|c|}
\hline \multirow{2}{*}{$\begin{array}{l}\text { SEAREX Sample + } \\
\text { Identification }\end{array}$} & \multicolumn{3}{|c|}{ Cascade Imp } & \multicolumn{3}{|c|}{ Stage Number } & \multirow{2}{*}{$\begin{array}{c}\text { Back up filter } \\
<0.25\end{array}$} & \multirow{2}{*}{$\frac{\text { Bulk filter }}{\Sigma}$} \\
\hline & $\begin{array}{l}\text { App. Part } \# \\
\text { Radius ( } \mu \mathrm{m})\end{array}$ & $>3.6$ & $\begin{array}{l}2 \\
1.5\end{array}$ & $0^{3}$ & $0^{4} .48$ & $0^{5} .25$ & & \\
\hline $\begin{array}{l}\text { IMPACTOR Dry Season } \\
7900026,6130 \mathrm{~m}^{3} \\
(4 / 22 \text { to } 4 / 29.79)\end{array}$ & $\begin{array}{l}\mathrm{Na} \\
\mu g \cdot \mathrm{m}^{-3}\end{array}$ & 1.90 & 3.60 & 1.10 & 1.20 & 0.90 & 0.50 & 5.80 \\
\hline $\begin{array}{l}\text { BULK FILTER } \\
\text { Dry Season } \\
7900021,7540 \mathrm{~m}^{3} \\
(4 / 22 \text { to } 4 / 29.79)\end{array}$ & $\begin{array}{l}P 0 C \\
n g . m^{-3} \\
\delta^{13 C} \% \circ\left\{\begin{array}{l}a- \\
b\end{array}\right.\end{array}$ & $\begin{array}{r}<50 \\
-22.8 \\
b-23 \pm 3\end{array}$ & $\begin{array}{l}<50 \\
-23.7 \\
-24 \pm 3\end{array}$ & $\begin{array}{l}<50 \\
-21.9 \\
-21 \pm 3\end{array}$ & $\begin{array}{r}<50 \\
-24.6 \\
-26 \pm 3\end{array}$ & $\begin{array}{r}<50 \\
-24.4 \\
-25 \pm 3\end{array}$ & $\begin{array}{l}930 \\
-26.6 \\
-27.2 \pm 0.5\end{array}$ & $\begin{array}{l}740 \\
-26.0 \\
-26.5 \pm 0.5\end{array}$ \\
\hline \multirow{3}{*}{$\begin{array}{l}\text { IMPACTOR Dry Season } \\
7900072,10669 \mathrm{~m}^{3} \\
(5 / 7 \text { to } 5 / 18.79) \\
\text { BULK FILTER } \\
\text { Ory Season } \\
7900073,6158 \mathrm{~m}^{3} \\
(5 / 7 \text { to } 5 / 12.79)\end{array}$} & $\begin{array}{l}\mathrm{Na} \\
\mu g \cdot \mathrm{m}^{-3}\end{array}$ & 2.50 & 2.80 & 0.50 & 0.40 & 0.24 & 0.16 & 7.00 \\
\hline & $\begin{array}{l}P \circ C \\
\mathrm{ng} \cdot \mathrm{m}^{-3}\end{array}$ & $\begin{array}{r}50 \\
-18.7\end{array}$ & $\begin{array}{l}<50 \\
-21.8\end{array}$ & $\begin{array}{r}50 \\
-22.1\end{array}$ & $\begin{array}{r}140 \\
-30.5\end{array}$ & $\begin{array}{r}70 \\
-27.2\end{array}$ & $\begin{array}{r}620 \\
-27.2\end{array}$ & $\begin{array}{l}1200 \\
-25.6\end{array}$ \\
\hline & & $p-17 \pm 3$ & $-21 \pm 3$ & $-2 i \pm 3$ & $-32 \pm 1$ & $-30 \pm 1$ & $-27.9 \pm 0.5$ & $-26.6 \pm 0.5$ \\
\hline \multirow{2}{*}{$\begin{array}{l}\text { IMPACTOR Wet Season } \\
79 \text { 00 } 246,9650 \mathrm{~m}^{3} \\
(7 / 12 \text { to } 7 / 21.79) \\
\text { BULK FILTER } \\
\text { Wet Season } \\
79 \text { o0 } 244,9430 \mathrm{~m}^{3} \\
(7 / 12 \text { to } 7 / 21.79)\end{array}$} & $\begin{array}{l}\mathrm{Na} \\
\mu \mathrm{g} \cdot \mathrm{m}^{-3}\end{array}$ & 1.30 & 1.10 & 0.20 & 0.20 & 0.15 & 0.25 & 3.80 \\
\hline & $\begin{array}{l}P \circ C \\
n g \cdot m^{-3} \\
\varepsilon^{13} C \% \circ\left[\begin{array}{l}a \\
b\end{array}\right.\end{array}$ & $\begin{array}{r}<50 \\
a-23.6 \\
b-23+1\end{array}$ & $\begin{array}{l}<50 \\
-22.5 \\
-21 \pm 1\end{array}$ & $\begin{array}{r}50 \\
-22.9 \\
-21 \pm 1\end{array}$ & $\begin{array}{r}<50 \\
-23.7 \\
-22 \pm 1\end{array}$ & $\begin{array}{l}<50 \\
-24.5 \\
-24.5 \pm 1\end{array}$ & $\begin{array}{l}820 \\
-27.0 \\
-27.3 \pm 0.3\end{array}$ & $\begin{array}{l}730 \\
-26.5 \\
-26.7 \pm 0.3\end{array}$ \\
\hline
\end{tabular}

+ Numbers $7900 \times x \times$ refer to the SEAREX data center sample identification number

+ According to the manufacturer, equivalent aerodynamic radius cut offs at $50 \%$ collection efficiency for particles with a density of $1 \mathrm{~g} . \mathrm{cm}^{-3}$.

Uncertainties for concentration measurements on $20 \times 25 \mathrm{~cm}$ filters (back up + bulk) are : for Na 0.1 ug. $\mathrm{m}^{-3}$, for POC $50 \mathrm{ng} . \mathrm{m}^{-3}$, and on impactor stages filter collection surfaces: for Na $0.2 \mu \mathrm{g} . \mathrm{m}^{-3}$, for POC 50 ng. $\mathrm{m}^{-3}$. For $\delta^{13} \mathrm{C}$ data, line a refers to values with no blank correction and line $\underline{b}$ to values after substraction of the blank contribution (Table 1) for each sample.

by Hoffmam and Duce (1977). Direct evidence of the presence of individual organic compounds of marine origin in marine aerosols has beer shown for low molecular weight fatty acids over the I'ropical North Atlantic (Martv et al., 1979) and at Enewetak (Gagosian et al., 1981).

When considering the range of $\delta^{13} \mathrm{C}$ values for bulk filter samples (Tables 2 and 3 ), the Sargasso Sea samples are slightly enriched in $\delta^{13} \mathrm{C}$ compared to the Enewetak samples. Although these differences are significant, $\sim 1 \%$, no explanation can be offered at present owing to the uncertainty on the $\delta^{13} \mathrm{C}$ of the primary sources, either continental or marine, of atmospheric POC in each of these geographical areas.

The fact that most of the atmospheric POC in marine aerosols appears to have a continental origin raises the question of how and in which form continental organic carbon is transported to the remote marine atmosphere. There is evidence that an initial emission in the vapor phase is involved at the source since most of the POC of continental origin in our atmospheric samples is found in the smallest particle size range (Duce, 1978). Results obtained from the Enewetak site by other investigators for individual compounds having a continental origin, natural (Gagosian et al.,1981) or man-made (Atlas and Giam, 1981), are consistent with this hypothesis since many of these compounds have a vapor phase precursor. Another argument comes from the fact that, at Enewetak, total atmospheric POC shows little variation of its concentration between the dry and the wet seasons
(Table 2), as is the case for some individual organic compounds (Gagosian et al., 1981 ; Atlas and Giam, 1981). This is not the case for mineral dust particles originating from soils. Indeed, this component shows a drop in concentration of almost 2 orders of magnitude between the dry and the wet

TABLE 3. Results for Sargasso Sea samples

\begin{tabular}{|c|c|c|c|}
\hline $\begin{array}{l}\text { SEAREX sample } \\
\text { icentification }\end{array}$ & $\frac{\mathrm{Na}}{4 \mathrm{~g} \cdot \mathrm{m}^{-3}}$ & $\begin{array}{l}\text { FOC } \\
n g .2^{-3}\end{array}$ & $\delta^{13} \mathrm{C} \%$ \\
\hline $\begin{array}{l}7928001,6640 \mathrm{~m}^{3} \\
(7 / 09 \text { to } 7 / 13.79) \\
36^{\circ} 27^{\prime} \mathrm{N} \& 67^{\circ} 33^{\prime} \mathrm{W} \\
=035^{\circ} 10^{\prime} \mathrm{N} \& 65^{\circ} 28^{\prime} \mathrm{W}\end{array}$ & 9.5 & 430 & $-25.5 \pm 0.3$ \\
\hline $\begin{array}{l}7328007,6640 \mathrm{~m}^{3} \\
(7 / 13 \text { to } 7 / 18.79) \\
3^{\circ} 10^{\prime} \mathrm{N} \& 65^{\circ} 28^{\prime} \mathrm{W} \\
\text { to } 32^{\circ} 38^{\prime} \mathrm{N} \& 66^{\circ} 06 \mathrm{~W}\end{array}$ & 3.6 & 480 & $-25.3 \pm 0.3$ \\
\hline $\begin{array}{l}7928012,7430 \mathrm{~m}^{3} \\
(7 / 18 \text { to } 7 / 23.79) \\
32^{\circ} 38^{\prime} \mathrm{N} \& 66^{\circ} 06^{\prime} \mathrm{W} \\
\text { to } 33^{\circ} 20^{\prime} \mathrm{N} \& 66^{\circ} 54^{\prime} \mathrm{W}\end{array}$ & 1.0 & 380 & $-25.4 \pm 0.3$ \\
\hline $\begin{array}{l}7928019,3755 \mathrm{~m}^{3} \\
(7 / 18 \text { to } 7 / 23.79) \\
33^{\circ} 20^{\prime} \mathrm{N} \& 66^{\circ} 54^{\prime} \mathrm{W} \\
\text { to } 39^{\circ} 00^{\prime} \mathrm{N} \& 71^{\circ} 00^{\prime} \mathrm{W}\end{array}$ & 0.2 & 450 & $-26.4 \pm 0.3$ \\
\hline
\end{tabular}

+ Numbers $79280 \times x$ refer to the SEAREX data center sample identification number.

Uncertainties for concentration measurements are the same as those given in Table 2. All results are biank corrected. 
seasons (Duce et al., 1980). Thus, direct production of organic carbon in the particulate form from continental sources seems unlikely. At the present stage, however, we do not know if the production of POC from a vapor phase organic carbon pool of continental origin takes place close to the source or in the marine atmosphere itself. Residence times of vapor phase precursors of atmospheric POC of corstinental origin are still poorly known.

\section{Conclusion}

We report here the first determination of the stable carbon isotopic composition of particulate organic carbon in the remote marine atmosphere. Our results indicate that long-range transport of organic carbon of continertal origin, natural and/ or man-made, is the major source for the organic component of marine aerosols in the tropical marine atmosphere of the North Pacific and the North Atlantic. This component accounts for more than $80 \%$ of the total coicentration of organic material in marine aerosols and is mainly presert in the smallest particle size range $(r<0.25 \mu \mathrm{m})$. Such an occurrence is likely due to the production in the marire atmosphere itself of particulate organic carbon from a vapor phase organic carbon pool of continental origin. The particulate organic carbon in the large size fraction of marine aerosols (less than $20 \%$ of the total concentration) has probably a direct marine origin since its carbon isotopic composition is close to the one expected for particulate organic carbon associated with seasalt droplets transported to the marire atmosphere.

Acknowledgements. We wish to thank the SEAREX Operation Group at University of Rhode Island for logistic support and sample collection at Enewetak. Helpful discussions with R.A. Duce, J-C. Duplessy and K.K. Turekian are gratefully appreciated. Two of us, U.E. and C.E.L. were supported by a SEAREX NSF grant, through a sub-contract with the University of Rhode Island. We wish to thank E. Hoffman and an anonymous reviewer for their useful comments.

\section{References}

Atlas, E. and C.S. Giam, Global transport of organic pollutants : ambient concentrations in the remote marine atmosphere, Science, 20, 163, 1981

Duce, R.A., Speculations on the budget of particulate and vapor phase non methane organic carbon in the global troposphere, Pure and Appl. Geophys., 116, 244, 1978 .

Duce, R.A., SEAREX : A multi-institutional inves- tigation of the sea/air exchange of pollutants and natural substances, Mar. Poll. Transfer Processes, Elsevier Sci. Pub. Co., Amsterdam, in press.

Duce R.A., C.K. Unni, B.J. Ray, J.M. Prospero and J.T. Merrill, Long-range atmospheric transport of soil dust from Asia to the Tropical North Pacific : Temporal Variability, Science, 209, 1522, 1980.

Eadie, B.J., L.M. Jeffrey and W.M. Sackett, Some observations on the stable carbon isotope composition of dissolved and particulate organic carbon in the marine environment, Geochim. Cosmochim. Acta, 42, 1265, 1978.

Eichmann, R., G. Ketseridis, G. Schebeke, R. Jaenicke, J. Hahn, P. Wanneck and C. Junge, NAlkane studies in the troposphere-II: gas and particulate concentrations in Indian Ocean Air, Atmos. Environ., 14, 695, 1980.

Fontugne, M. and J-C. Duplessy, Carbon isotope ratio of marine plankton related to surface water masses, Earth Planet. Sci. Lett., 41, 365, 1978 .

Fontugne, M. and J-C. Duplessy, Organic carbon isotopic fractionation by marine plankton in the temperature range -1 to $31^{\circ} \mathrm{C}$, Oceanol. Acta $4,85,1981$.

Gagosian, R.B., E.T. Peltzer, and 0.C. Zafiriou, Atmospheric transport of continentally derived lipids to the Tropical North Pacific, submitted to Nature.

Hoffman, E.J. and R.A. Duce, Organic carbon in marine atmosphere particulate matter : concentration and particle size distribution, Geophys. Res. Lett., 4 4 449, 1977.

Marty, J.C., A. Saliot, P. Buat-Menard, R. Chesselet and K. Hunter, Relationship between the lipid compositions of marine aerosols, the seasurface microlayer and subsurface water, J. Geophys. Res., 84, 5707, 1979.

Parker, P.L., Petroleum-stable isotope ratio variations, Impingement of man on the oceans, 431, $\mathrm{J}$. Wiley and Sons, New York, 1971.

Sackett, W.M., The depositional history and isotopic organic carbon composition of marine sediments, Mar. Geol., 2, 173, 1964.

Sharp, J.M., Improved analysis for particulate organic carbon and nitrogen from seawater, Limnol. Oceanogr., 19, 984, 1974.

Williams, P.M. and L.I. Gordon, Carbon 13 : Carbon 12 ratios in dissolved and particulate organic matter in the sea, Deep Sea Res., 17, 19, 1970 .

(Received December 1, 1980; accepted January 23, 1981.) 